realities. The paper reveals certain aspects of the development of science of the $20^{\text {th }}$ century that influenced the formation of the Theory.

Keywords: Theory, postmodernism, new ethics, reasons for success, factors

ПЕТРОВ Вячеслав Константинович - кандидат философских наук, главный редактор сайта «Политическое образование», научный руководитель Школы молодого этнополитолога, член Экспертного совета при Федеральном агентстве по делам национальностей (vp230754@таil.ru) ПЕТРОВА Марина Юрьевна - кандидат психологических наук, заместитель главного редактора сайта «Политическое образование», эксперт Школь молодого этнополитолога (тр210260@ mail.ru)

\title{
РУССКИЙ ЯЗЫК КАК ОСНОВА РУССКОЙ АНАЛИТИКИ
}

Аннотация. В современных исследованиях, посвященных отечественной аналитике, полностью отсутствуют собственные подходы, соответствующие русской ментальности и русской аналитической традиции. В статье высказывается предположение, что специфическая русская аналитика существует, и доказывается этот тезис исходя из своеобразия и уникальности русского языка (в т.ч. философского). Авторы приходят к выводу, что русская аналитика начинается с овладения всем богатством русского языка и предлагают существенно дополнить учебные программы подготовки аналитиков изучением русской философской традиции, функционального языкознания и психолингвистики.

Ключевые слова: русская философская традиция, специфическая русская аналитика, своеобразие и уникальность русского языка, учебные программы подготовки аналитиков

Сегодня, когда речь заходит об отечественной аналитике, все внимание сосредоточивается на ее институционализации, координации и встраивании в международное интеллектуальное сообщество. Этому посвящен целый ряд исследований, в которых эти вопросы раскрываются с разной степенью глубины и детализации. Единственное, что объединяет все эти работы, - отсутствие даже намека на выработку собственных подходов, соответствующих русской ментальности и русской аналитической традиции.

Возьмем, к примеру, аналитический доклад Экспертного института социальных исследований «Интеллектуальная экспансия. Российские “фабрики мысли": возможности влияния в международном экспертно-политическом пространстве» ${ }^{1}$. В нем подчеркивается, что «организация и деятельность таких центров исторически обусловлена спецификой страны, ее традиций науки и образования, принципами научного познания, разделяемыми в интеллектуальной элите общества... Для России, пережившей драматические сломы государственности на протяжении XX века, представляется крайне важным учет особенностей работы таких структур за рубежом и использование собственных наработок, имеющихся по широкому спектру исследовательских направлений (политические институты и процессы, международные отношения и мировая политика, зарубежное и отечественное регионоведение, конфликтология и др.)». Если бы не это упоминание России во введении доклада, вообще непо-

1 https://eisr.ru/projects-and-researches/intellektualnaya-ekspansiya-rossiyskie-fabriki-myslivozmozhnosti-vliyaniya-v-mezhdunarodnom-ekspert/ (проверено 16.01.2022). 
нятно было бы, о какой стране идет речь, а под «собственными наработками» авторы доклада, судя по всему, понимают некие новации в технологическом процессе и процедурах анализа.

То же самое можно сказать и о работах Ю.В. Курносова, одного из основателей Русской аналитической школы [Курносов 2012]. Они не дают ответ на вопрос, существует ли на самом деле «русская аналитика», и если да, то в чем ее сущность?

Абсолютно не раскрыта эта тема и в Концепции русской аналитической школы [Курносов 2013: 219-223], которая, по логике вещей, должна была стать основополагающим доктринальным документом данного проекта.

Словосочетание «русская аналитика» в документе встречается только один раз, и то - в заголовке. В Концепции школа предстает как еще один масштабный бизнес-проект, претендующий в абсолюте на роль очередной госмонополии или, по крайней мере, на появление на рынке консалтинговых услуг мегасубъекта, который окончательно вытеснит существующие ныне малочисленные группы аналитиков, может быть, к слову, вполне эффективно действующие.

Ознакомление с Концепцией наталкивает на вопрос: что русского в этой аналитической школе? Чем русская аналитика отличается, например, от англосаксонской? Ни слова не сказано о национально-цивилизационных особенностях аналитики (институциональных и содержательных). Может быть, это прозвучит резко, но складывается впечатление, что у основателей данного проекта вся «русскость» вылилась в гигантоманию и этатизм, в стремление как можно теснее «прижаться к государству».

И все же, существует ли «русская аналитика»? Многочисленные дискуссии авторов с философами, политологами, политическими аналитиками выявили две противоположные точки зрения. Одни считают, что раз современная аналитика пришла к нам с Запада, то никакой русской школы аналитики не существует, а если и есть, то она носит имитационный характер. Другие утверждают, что специфическая русская аналитика существует, ссылаясь на богатейшую русскую философскую научную и культурную традиции. Так кто же из них прав?

Казалось бы, как аналитика может быть русской, английской, французской и т.д.? Ведь по определению аналитика - это исследование какой-либо проблемы методами рационального мышления, а мышление, в свою очередь, опирается на законы логики, которые носят общечеловеческий характер и у всех людей одинаковы (иначе бы люди не понимали друг друга).

Но, с другой стороны, в философии XX в. не раз высказывалась мысль, что существует не один, а несколько разных типов мышления. Укажем, к примеру, на идею К. Леви-Стросса о неевропейском, «первобытном» мышлении, основанном на бриколаже ${ }^{1}$ [Леви-Стросс 1994]. В различных странах имеются свои школы науки и образования, исследовательские аналитические традиции. О. Шпенглер считал, что даже математика и физика у разных цивилизаций отличаются. По сути, такого же мнения придерживался российский философ, культуролог и литературовед доктор филологических наук Г.Д. Гачев с его идеей национальных космо-психо-логосов [Гачев 2007]. Сродни этой идее теория культурно-исторических типов Н.А. Данилевского [Данилевский 1991], работы создателей «русской метафизики» Г.П. Щедровицкого, М.К. Мамардашвили,

\footnotetext{
1 Бриколаж - термин, использующийся в различных дисциплинах, в т.ч. в изобразительном искусстве, литературе и философии, означающий создание предмета или объекта из подручных материалов, а также сам этот предмет или объект.
} 
М.В. Раца, О.С. Анисимова, специалистов по субъектно-ориентированному подходу В.Е. Лепского и цивилизационной психологии А.И. Юрьева, Н.М. Ракитянского [Ракитянский 2020], а также Л.С. Выгодского, изучавшего взаимоотношения мышления и речи, культурологические исследования Д.С. Лихачева, В.Н. Топорова, В.В. Иванова, С.С. Аверинцева, А.Я. Гуревича и др.

Но даже если предположить, что мышление у всех одинаково, языки, посредством которых люди выражают мысли как результат мыслительной деятельности, разные. К тому же одна и та же мысль на разных языках обнаруживает разные аспекты. В полной мере это относится и к русскому языку с его эмоциональностью и интонационным богатством, что предопределяет такую отличительную особенность русской аналитики, как человекоразмерность. Для русского аналитика важно не только рациональное объяснение, но и реализация нравственных идеалов (добра, справедливости). По мнению Г.Д. Гачева, это и составляет основу русского национального Логоса. Ученый отмечает, что мы ежедневно задаемся вопросами: «Что? Почему? Зачем? Как? Кто?», но у разных народов в силу разной ментальности ответы на них будут различаться, порой существенно. Если у греков они объединены в один «Ti to on?» - «Что eсть?», то у немцев в центре внимания стоит вопрос «Warum?»- «Почему?»), их интерес направлен к происхождению, к причинам вещей, обращен в глубины прошлого. «Warum?» - это «Was um?» - «Что вокруг?». При этом Мир предполагается состоящим из двух частей: «Я» и «не-Я» (философия Фихте) $)^{1}$.

У французов этот вопрос имеет вид «Pour-quoi?» - «Для чего? Зачем?». Здесь уже важнее цель нежели причины, а сущность всего полагается лежащей в будущем. Как отмечают эксперты, отсюда возникли теории прогресса (Руссо, Кондорсе), эволюции (Ламарк, Бергсон, Тейяр де Шарден), социальные утопии (Сен-Симон, Фурье, Конт).

У поляков вопрос «Почему?» в смысле «Для чего?», что роднит их с французами. Отсюда и взаимное притяжение между Польшей и Францией в политике и культуре и отталкивание от Германии.

Для целей нашего исследования представляет интерес семантическая классификация языков, предложенная выдающимся швейцарским лингвистом Ш. Балли [Балли 1955]. Он выделяет две противоположные «психологические тенденции», находящие свое проявление в синтаксисе языков: импрессионистическую (отражение явлений с точки зрения их восприятия) и аналитическую (рационалистическое представление отношений между причиной и следствием). На основе этой гипотезы автор располагает языки на шкале психологической ориентации по степени проявления в них двух выделенных им психологических тенденций. Русский язык - язык абсолютно импрессионистической ориентации, английский - аналитической ориентации, немецкий язык - ближе к русскому, в отличие от французского, который ближе к английскому.

Опираясь на классификацию языков Ш. Балли, польский и австралийский лингвист А. Вежбицка разработала свою концепцию этносинтаксиса [Wierzbicka 1988]. В соответствии с картированием концепта каузативности как в лексике, так и в грамматике языка эта концепция позволяет относить английский язык к языкам аналитической ориентации, отдающим приоритет рационалистическому представлению отношений между явлениями объективного мира в терминах причины и следствия, что, в свою очередь, отра-

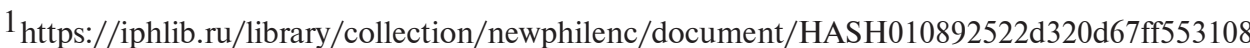
(проверено 16.01.2022).
} 
жает особенности менталитета нации. Напротив, в русском языке как языке импрессионистической направленности более подробную репрезентацию как на лексическом, так и на грамматическом уровне находит эмоциональное состояние человека, переживаемые им эмоции. (Для сравнения: на русском языке «ему тоскливо», «он тоскует», «у него тоска», «он в тоске» и he's sad - на английском).

Кроме того, в своих исследованиях А. Вежбицка выделила главные черты русского этнического характера. В статье «Русский язык» она, опираясь на анализ русской лексики, отметила особенности русской культуры и менталитета ${ }^{1}$. Автор считает, что «в наиболее полной мере особенности русского национального характера раскрываются и отражаются в трех уникальных понятиях русской культуры», а именно - «душа», «судьба» и «тоска». Анализируя данные слова (и множество других), Вежбицка и находит те семантические свойства, которые характеризуют русский менталитет: эмоциональность, «иррациональность» («нерациональность»), неагентивность и любовь к морали.

Отметим, что во всех этих исследованиях в том или ином виде подчеркивается определяющее значение языка для формирования цивилизационной (общей) и индивидуальной (событийной) картины мира, и, более того, роль языка в этом настолько велика, что даже высказывается мнение, что не мозг управляет языком, а язык управляет мозгом.

В самом деле, язык - это отражение картины нашего мира, типа нашего поведения. Мы видим, что архетипы нашего сознания четко прослеживаются в русском языке. Наш язык диктует нам, как поступать в той или иной ситуации. У русских и англосаксов с западноевропейцами разное понимание деятельности, и это четко прослеживается в языке. Так, западные народы строят всю свою грамматику на 2 глаголах: «иметь» и «желать». Например, в английском языке прошедшее время I have been в дословном переводе означает «я имел был», а в будущем времени - will, который несет в себе смысловую нагрузку проявления воли, твердого намерения. Таким образом, два глагола, скрепляющих всю грамматику английского языка, формируют и в сознании носителей этого языка стремление желать и обладать. То же самое относится к немецкой и французской грамматике.

А в русском языке есть только глагол «быть» («я был», «я жил», «я буду»), и это влияет на наше сознание. Мы имеем дело с действительностью, не рассматривая ее как объект овладения и желания. Формула владения у нас чрезвычайно интересная: там, где англичанин говорит I have, а немец - ich habe - «я имею», мы говорим «у меня есть»- «мне дано» 2 .

Особенности русской грамматики предопределяют иной взгляд на окружающий мир. Так, в нашем языке существуют три слова, относящихся к деятельности - «дело» (что-то важное, интересное), «труд» (что-то трудное, но достойное уважения) и «работа» (что-то неинтересное, муторное). Отношение к «работе» можно проиллюстрировать пословицей: «Работа - не волк, в лес не убежит».

Добавим, что русский язык (как и латынь) - флективный (от лат. flectivus гибкий), синтетический, т.е. флексии (суффиксы, окончания и пр.) выражают сразу несколько грамматических значений. Это обусловливает (в отличие от английского) свободный порядок слов в русском предложении, что позволяет выразить тонкие оттенки смысла, настроения, расставить акценты.

\footnotetext{
1 Язык. Культура. Познание. М.: Русские словари. 1996. С. 33-88.

2 Русский язык - зеркало национального сознания. Доступ: https://www.planet-kob.ru/ articles/705 (проверено 16.01.2022).
} 
Как можно экстраполировать это на русскую аналитику? Получается интересно: русский аналитик, в отличие от, например, американского, должен быть убежден, что возможности рационального описания, как и способность контролировать жизненные события, ограничены. Отсюда наша недостаточная выделенность как автономного агента, как лица, стремящегося к своей цели и пытающегося ее достичь, как контролера событий. Другими словами, по мнению авторов, на Западе социальные закономерности воспринимаются как нечто созданное суммой воль индивидов, у нас - как некие внешние по отношению к нам законы, которым мы не можем не подчиняться («судьба»).

Еще одним тонким духовным моментом, отличающим русскоязычного мыслителя, является своеобразное доверие к языку. Люди, говорящие на русском языке, а тем более философы, полагают язык сотоварищем по творчеству, а не просто средством выражения мысли.

Авторы уверены, что русская аналитика начинается с овладения всем богатством русского языка, и предлагают существенно дополнить учебные программы подготовки аналитиков изучением русской философской традиции, функционального языкознания и психолингвистики. Делать это надо в тесном контакте с учеными и практиками, работающими в соответствующих областях знаний.

Все это позволит подготовить аналитиков-профессионалов, которые будут способствовать упреждающему развитию нашей страны, созданию новых фундаментальных понятий (ибо в них возникает новая система), новой методологии преодоления существующих проблем и построения будущего.

Безусловно, в одной статье раскрыть всеобъемлющую роль русского языка в аналитике невозможно. Но мы и не ставили такую задачу. Главный вывод, вытекающий из изложенного: можно и нужно говорить о феномене русской аналитической традиции в неразрывной связи с русским (в т.ч. философским) языком, и этот феномен необходимо внимательно изучать и эффективно использовать. Ведь немецкий философ, основатель «философской герменевтики» Г.-Г. Гадамер верно заметил: «Язык есть нечто большее. Он есть всеобъемлющая предвосхищающая истолкованность мира и в этом смысле ничем не заменим. Прежде всякой философски нацеленной, критической мысли мир является для нас всегда уже миром, истолкованным в языке. С изучением языка, с нашим врастанием в родной язык мир становится для нас членораздельным» [Гадамер 1991: 29].

Статья подготовлена в рамках работы Школы молодого этнополитолога (проект Фонда президентских грантов № 21-2-00592).

\section{Список литературы}

Балли Ш. 1955. Общая лингвистика и вопросы франиузского языка (пер. с 3-го фр. изд. Е.В. и Т.В. Вентцель; ред., вступ. статья и прим. Р.А. Будагова). М.: Издательство иностранной литературы. 416 с.

Гадамер Г.-Г. 1991. Актуальность прекрасного. М.: Искусство. 367 с.

Гачев Г.Д. 2007. Национальные образы мира. Космо-Психо-Логос.

Сер. Технологии культуры. М.: Академический Проект. 512 с.

Данилевский Н.Я. 1991. Россия и Европа (сост., посл. и ком. С.А. Вайгачева). М.: Книга. 574 с.

Курносов Ю.В. 2012. Аналитика как интеллектуальное оружие. М.: Русаки. $613 \mathrm{c}$.

Курносов Ю.В. 2013. Азбука аналитики. М.: Русаки. 230 с. 
Леви-Стросс К. 1994. Первобытное мышление. М.: Республика. 384 с.

Ракитянский Н.М. 2020. Ментальные исследования глобальных политических миров. М.: Изд-во МГУ. 463 с.

Wierzbicka A. 1988. The Semantics of Grammar. Amsterdam: John Benjamins. 617 p.

PETROV Vyacheslav Konstantinovich, Cand.Sci. (Philos.), Editor-in-Chief of the website «Political Education», Deputy Head of the Young Ethnopolitologist School, Member of the Federal Agency for Nationalities Expert Council (vp230754@ mail.ru)

PETROVA Marina Yuryevna, Cand.Sci. (Psych.), member of the website «Political Education» editorial board, expert of the Young Ethnopolitologist School (mp210260@mail.ru)

\section{RUSSIAN LANGUAGE AS THE BASIS OF RUSSIAN ANALYTICS}

\footnotetext{
Abstract. Russian analytical studies completely lack their own approaches that correspond to the Russian mentality and the Russian analytical tradition. The article states, that Russian analysis exists, and proves this thesis based on the originality and uniqueness of the Russian language (including philosophical one).

The authors come to conclusion that Russian analytics begins with the acquisition of the entire wealth of the Russian language, and they propose to supplement the training programs for analysts significantly with the study of the Russian philosophical tradition, functional linguistics and psycholinguistics.

Keywords: Russian philosophical tradition, specific Russian analytics, originality and uniqueness of Russian language, training programs for analysts
} 